\title{
BMJ Open Social distribution of diabetes, hypertension and related risk factors in Barbados: a cross-sectional study
}

\author{
Christina Howitt, ${ }^{1}$ lan R Hambleton, ${ }^{1}$ Angela M C Rose, ${ }^{1}$ Anselm Hennis, ${ }^{2}$ \\ T Alafia Samuels, ${ }^{3}$ Kenneth S George, ${ }^{4}$ Nigel Unwin ${ }^{1,5}$
}

To cite: Howitt $\mathrm{C}$, Hambleton IR, Rose AMC, et al. Social distribution of diabetes, hypertension and related risk factors in Barbados: a crosssectional study. BMJ Open 2015;5:e008869.

doi:10.1136/bmjopen-2015008869

\section{- Prepublication history and additional material is available. To view please visit the journal (http://dx.doi.org/ 10.1136/bmjopen-2015- 008869)}

Received 22 May 2015 Revised 16 October 2015 Accepted 26 October 2015

\section{CrossMark}

\author{
${ }^{1}$ Chronic Disease Research \\ Centre, Tropical Medicine \\ Research Institute, \\ The University of the \\ West Indies, Bridgetown, \\ Barbados \\ ${ }^{2}$ Faculty of Medical Sciences, \\ The University of the \\ West Indies, Cave Hill, \\ Barbados \\ ${ }^{3}$ Department of Non- \\ communicable Diseases and \\ Mental Health, Pan American \\ Health Organization, \\ Washington, USA \\ ${ }^{4}$ Ministry of Health, \\ Bridgetown, Barbados \\ ${ }^{5}$ MRC Epidemiology Unit, \\ University of Cambridge, \\ Cambridge, UK
}

\section{Correspondence to} Christina Howitt; christina.howitt@cavehill.uwi. edu

\section{ABSTRACT}

Objective: To describe the distribution of diabetes, hypertension and related behavioural and biological risk factors in adults in Barbados by gender, education and occupation.

Design: Multistage probability sampling was used to select a representative sample of the adult population ( $\geq 25$ years). Participants were interviewed using standard questionnaires, underwent anthropometric and blood pressure measurements, and provided fasting blood for glucose and cholesterol measurements. Standard WHO definitions were used. Data were weighted for sampling and non-response, and were age and sex standardised to the 2010 Barbados population. Weighted prevalence estimates were calculated, and prevalence ratios were calculated for behavioural and biological risk factors by demographic and socioeconomic group.

Results: Study response rate was $55.0 \%$, with 764 women, 470 men. Prevalence of obesity was $33.8 \%$ (95\% Cl $30.7 \%$ to $37.1 \%$ ); hypertension $40.6 \%$ (95\% $\mathrm{Cl} 36.5 \%$ to $44.9 \%)$; and diabetes $18.7 \%(95 \% \mathrm{Cl}$ $16.2 \%$ to $21.4 \%$ ). Compared with women, men were less likely to be obese (prevalence ratio $0.5 ; 95 \% \mathrm{Cl}$ 0.4 to 0.7$)$, or physically inactive $(0.5 ; 0.4$ to 0.6$)$, but more likely to smoke tobacco $(4.1 ; 2.5$ to 6.7$)$ and consume large amounts of alcohol in a single episode (4.6; 2.7 to 7.6). Both diabetes $(0.83 ; 0.65$ to 1.05$)$ and hypertension ( $0.89 ; 0.79$ to 1.02$)$ were lower in men, but not significantly so. In women, higher educational level was related to higher fruit and vegetable intake, more physical activity, less diabetes and less hypercholesterolaemia ( $p$ 0.01-0.04). In men, higher education was related only to less smoking ( $p$ 0.04). Differences by occupation were limited to smoking in men and hypercholesterolaemia in women. Conclusions: In this developing country population, sex appears to be a much stronger determinant of behavioural risk factors, as well as obesity and its related risks, than education or occupation. These findings have implications for meeting the commitments made in the 2011 Rio Political Declaration, to eliminate health inequities.

\section{INTRODUCTION}

There is great interest globally in the social determinants of health and in the

\section{Strengths and limitations of this study}

- Diabetes, hypertension, obesity and hypercholesterolaemia were assessed objectively and were therefore not subject to the interviewee bias inherent in self-reported risk factor assessments.

- The cross-sectional design of the study did not allow for examination of temporal relationships.

- The numbers of participants for some analyses were small and the associated Cls were wide, which may have reduced our power to detect significant associations.

- The study response rate was relatively low, particularly among young men, which could affect the generalisability of the results.

- The survey weighting scheme ensured that estimates provided by age and sex are generalisable to the adult Barbadian population.

identification of health inequities, that is, avoidable or remedial differences in health between social groups. ${ }^{1}$ This interest is in large part attributable to the work of the WHO's Commission on the Social Determinants of Health, which was followed in 2011 by the Rio Political Declaration, ${ }^{2}$ in which countries committed to taking action to reduce health inequities. However, despite this interest and avowed political commitment, data on differences in health by social group are relatively scarce, and largely limited to wealthier, economically developed, nations.

The Caribbean is a middle-income region in which the majority of the burden of disease is due to chronic non-communicable diseases (NCDs), including diabetes, cardiovascular disease and cancers. ${ }^{3}$ The region is estimated to have one of the highest prevalences of diabetes in the world, with between $10 \%$ and $15 \%$ of the adult population affected. ${ }^{4}$ Age-adjusted rates of death from NCDs are higher in most Caribbean countries than in the USA or Canada. ${ }^{4}$ However, while it is well known that NCDs are the 
major contributor to the burden of disease in most Caribbean countries, there are very limited data on their distribution by social group. Such data are essential in order to identify health inequities and to guide interventions aimed at their reduction.

Data on the distribution of NCDs and their risk factors from high-income, economically developed nations, such as the USA, Canada, and the UK, indicate that type 2 diabetes, cardiovascular disease and their risk factors tend to occur at highest rates in the more disadvantaged social groups. ${ }^{5}{ }^{6}$ Data from developing regions are less clear, with limited evidence for higher levels of obesity initially in wealthier groups and a later transition to higher rates in socially disadvantaged groups with increasing national economic development. ${ }^{7}$

Barbados is an independent Caribbean country with a population of 277821,8 in which $80 \%$ of deaths are due to NCDs. ${ }^{9}$ It is considered a developing economy by the International Monetary Fund, ${ }^{10}$ yet it is classified by the World Bank as a high-income country, with an estimated gross domestic product per capita in 2012 of just under US $\$ 15000 .{ }^{11}$ It is a member of the United Nations Conference of Small Island Developing States (SIDS), which is a group of developing countries that face specific social, economic and environmental challenges to their economic development. ${ }^{12}$ It therefore provides an opportunity to characterise the social distribution of NCDs and associated risk factors in a high-income, developing country.

The overall aim of this paper is to contribute towards a more complete global picture of the distribution of diabetes, hypertension, and related behavioural and biological risk factors by social group. We collected nationally representative data in order to describe the distribution of diabetes, hypertension and related risk factors in adults in Barbados by sex, education and occupation. We discuss the implications of our findings for policy, practice and further research on health inequities in this and similar populations.

\section{METHODS}

\section{Survey design}

This study was a cross-sectional survey of the Barbadian population aged 25 years and over, with households selected from a national sampling frame maintained by the Barbados Government Statistical Service. The sample was obtained by selecting enumeration districts (EDs) with a probability proportional to their population size. From each ED, households were systematically selected after a random start on a predetermined route. A single participant was randomly selected from each household, using the Kish method. ${ }^{13}$ A record was kept of all selected households and the number of eligible residents in each, regardless of participation status, so that the non-response rate by ED could be calculated for appropriate analytical weighting.

\section{Data collection}

Data collection took place between September 2011 and May 2013. Registered nurses were recruited as data collection staff. Data collectors were assessed by a study investigator prior to starting, and every 6 months thereafter, to ensure that they followed the standard protocol for all measurements.

Data collection took place in the participants' homes over two visits. At the first visit, demographic characteristics, and information on socioeconomic position, behavioural risk factors (tobacco smoking, alcohol consumption, fruit and vegetable intake, and physical inactivity), hypertension and diabetes, were collected by standard questionnaire during a face-to-face interview. Demographic information was collected using the national census questionnaire, and risk factor information was collected using a questionnaire adapted from WHO STEPS. ${ }^{8} 14$ Measurements taken at this visit included weight (without footwear, wearing minimal, light clothing; measured using Seca Robusta 813 scales), height (without footwear or headwear; measured using Seca 217 stadiometers) and blood pressure (measured using Omron HEM-705CP digital automatic blood pressure monitors). Blood pressure was measured after the participant was seated quietly for at least $15 \mathrm{~min}$, with at least $3 \mathrm{~min}$ spent with the cuff and arm in the correct position for measurement (cuff placed at the midpoint of the right arm; arm resting with palm facing upwards). Three blood pressure readings were taken 3 min apart, with the participant resting in between each reading.

At the end of the first visit, a second visit was booked in order to collect a venous blood sample after the participant had fasted for at least $9 \mathrm{~h}$. Where possible, the second visit was booked for the morning after the first visit. The visit was rescheduled if the participant had not fasted but was willing to do so; however, if he or she was not willing, the sample was collected and the non-fasted status recorded. The sample was collected into separate vacutainer collection tubes for blood glucose and lipid analyses. The sample for glucose analysis was collected in a sodium fluoride tube and placed immediately in a container on wet ice until analysis (Roche Cobas 6000, Roche Diagnostics, Mannheim, Germany; glucose hexokinase method). The sample for lipid analysis was collected in an EDTA tube and was analysed using a Reflotron biochemical analyser (Roche Diagnostics, Mannheim, Germany). Manufacturers' recommended quality control procedures for all biochemical assays were followed throughout.

Written informed consent was obtained from all participants.

\section{Variable definitions}

Demographic and socioeconomic information, including participant age, sex, highest attained level of education and occupation, were ascertained by questionnaire. Education and occupation were used as markers of socioeconomic position. Education was grouped into 
four levels as follows: level 1 had not completed secondary school; level 2 completed secondary school; level 3 with technical, trade or teacher education; and level 4 with university education (undergraduate and postgraduate). Occupation was collected as free text and then coded using the Barbados Standard Occupational Classification (BARSOC-89), ${ }^{15}$ which is based on the 1988 International Standard Classification of Occupations (ISCO-88). ${ }^{16}$ BARSOC-89 contains nine major groups, which were collapsed to create three broad occupational categories as follows: group 1 (routine/manual) consisted of skilled agricultural, craft/elementary workers, and machine operators; group 2 (intermediate) comprised technical, clerical and service employees; and group 3 (professional) consisted of managers and professionals.

Data on diabetes, hypertension and six related risk factors were used in this analysis: tobacco use; heavy episodic alcohol consumption; inadequate fruit and vegetable intake; physical inactivity; obesity; and hypercholesterolaemia. Definitions for these conditions and risk factors are provided in table 1.

\section{Statistical methods}

Data were analysed using the Stata software package (V.13, StataCorp, College Station, Texas, USA). All analyses were weighted to account for the sampling design and ED level non-response, and to match the age-sex distribution of the Barbadian population according to the 2010 Barbados Population and Housing Census. ${ }^{8}$ Detailed information on how the survey weights were calculated and applied is provided in online supplementary appendix 1. Prevalence estimates were calculated for diabetes, hypertension and related risk factors. Prevalence ratios (PRs) were calculated using log binomial regression models, and were used to determine whether the prevalence of risk factors differed by demographic and socioeconomic group (defined by age, sex, education and occupation). When calculating PRs, the lowest category was used as the reference group: for comparisons by age, this was youngest group (2544 years); for education, this was 'less than secondary school'; and for occupation, this was 'routine/manual'. Estimates are presented with $95 \%$ CIs.

\section{RESULTS}

Figure 1 shows the stages of selecting and recruiting households and individuals to the study. Out of 3589 potential households approached by the Barbados Statistical Service, 858 were determined to be ineligible. Reasons for ineligibility are given in online supplementary table S1, with the single largest category (586) being that the buildings were obviously vacant. In addition, there were a further 454 potential households that were not obviously vacant but with which no contact could be established, including after five visits, eight phone calls (where a number was available) and sending a registered letter. Out of the 2277 households with which contact was established, $1646(72.3 \%)$ agreed to being approached by the study, and of these 1234 (75.0\%) eventually took part in the study. The best estimate of the overall response rate is therefore $54.2 \%(1234 / 2277)$.

The characteristics of participants in the final study sample are shown in table 2. Compared with the official population, provided by the 2010 Barbados Population and Housing Census, the survey generally undersampled young adults and oversampled the elderly, and more women than men took part. These discrepancies were addressed by the survey weighting scheme, as described in detail in online supplementary appendix 1 . The number of participants with missing data for each of the outcomes of interest by sex, educational and occupational category is shown in online supplementary tables S3 and S4.

\section{Prevalence and sex-specific patterns of risk factors}

The prevalence of diabetes, hypertension and associated risk factors by sex is shown in table 3, along with age-adjusted PRs for men versus women.

Table 1 Definition of diabetes, hypertension and associated risk factors

\begin{tabular}{ll}
\hline Risk factor & Definition \\
\hline Diabetes & $\begin{array}{l}\text { Self-reported doctor-diagnosed diabetes or fasting blood glucose } \geq 7 \mathrm{mmol} / \mathrm{L} \\
\text { If both data points are missing, or one is negative and the other is missing, the } \\
\text { participant is excluded from the denominator }\end{array}$ \\
$\begin{array}{ll}\text { Self-reported current use of antihypertensive medication, or a systolic blood pressure } \\
\geq 140 \mathrm{~mm} \mathrm{Hg} \text {, or a diastolic blood pressure } \geq 90 \mathrm{~mm} \mathrm{Hg}\end{array}$ \\
$\begin{array}{ll}\text { Bypertension } & \text { Self-reported use of any tobacco products, including cigarettes, cigars or pipes } \\
\text { Current tobacco use } & \text { Self-reported consumption of at least } 4 \text { (for females) or } 5 \text { (for males) standard } \\
\text { Heavy episodic alcohol consumption } & \text { alcoholic drinks in a single drinking occasion at least once in the past } 30 \text { days } \\
\text { Inadequate fruit and vegetable intake } & \begin{array}{l}\text { Self-reported intake of less than } 5 \text { servings of fruit and/or vegetables per day } \\
\text { Self-reported activity of less than } 150 \text { min of moderate intensity per week, assessed }\end{array} \\
\text { Physical inactivity } & \text { by the Recent Physical Activity Questionnaire }{ }^{17} \\
\text { Obesity } & \text { Body mass index of } 30 \mathrm{~kg} / \mathrm{m}^{2} \text { or more } \\
\text { Hypercholesterolaemia } & \text { Total cholesterol of } 5 \mathrm{mmol} / \mathrm{L} \text { or more }\end{array}$ \\
\hline
\end{tabular}




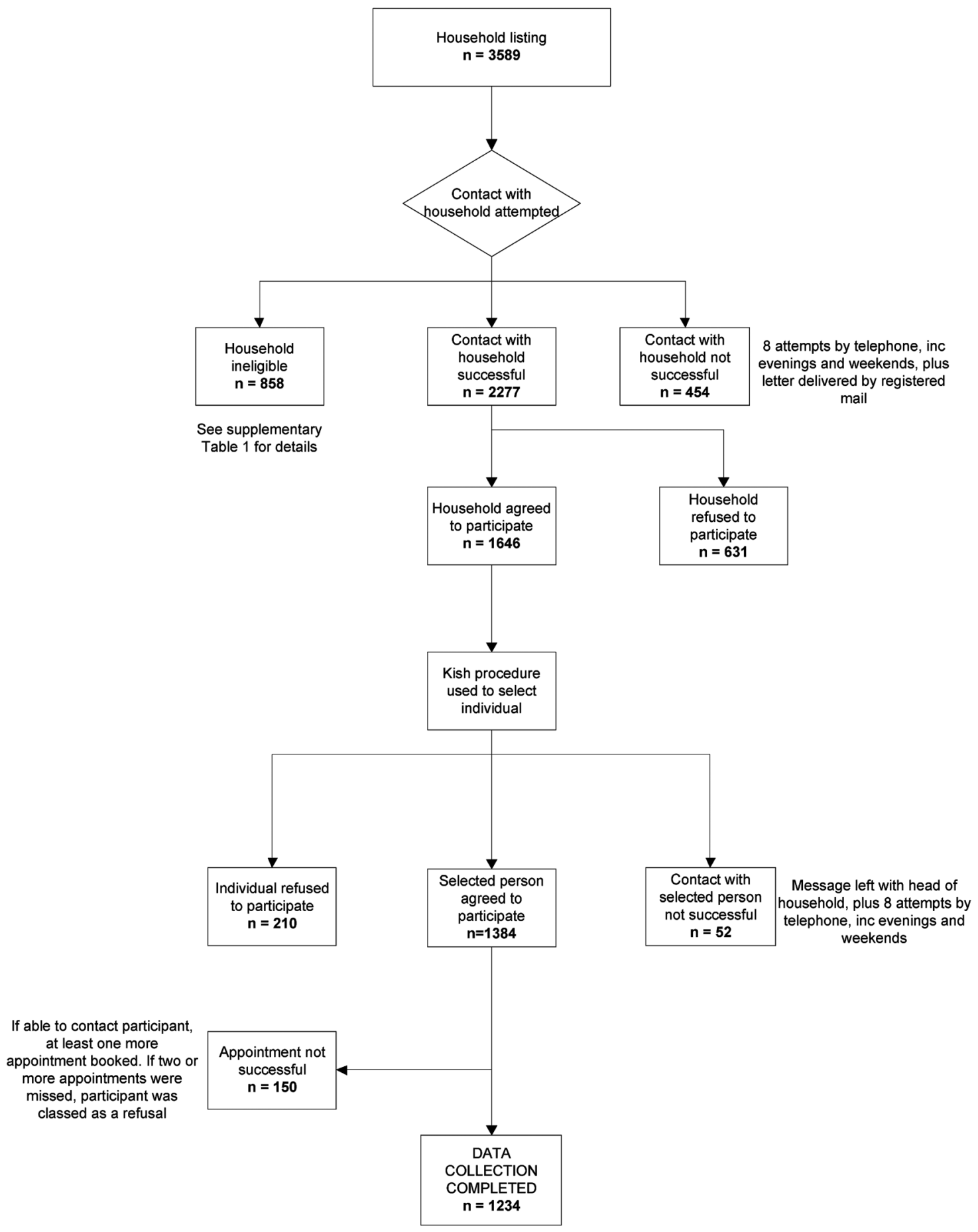

Figure 1 Survey recruitment.

Current tobacco use and heavy episodic alcohol consumption were relatively uncommon, with an overall prevalence of $9.2 \%(95 \%$ CI $7.2 \%$ to $11.7 \%)$ and $14.5 \%$ (12.0\% to $17.4 \%)$, respectively. Both were more than four times more prevalent in men than in women, with a PR of 4.08 (2.48 to 6.69) for current tobacco use, and a PR of 4.55 (2.70 to 7.58) for heavy episodic alcohol consumption. Inadequate fruit and vegetable intake was highly prevalent $(90.0 \% ; 87.0 \%$ to $92.4 \%)$, and was similar in both sexes. Physical inactivity was reported by $49.9 \%$ ( $46.1 \%$ to $53.7 \%$ ) of respondents, with inactivity about half as likely in men as women (PR 0.47; 0.39 to 0.57 ).

Levels of biological risk factors and conditions were high: $40.7 \%(36.4 \%$ to $44.8 \%)$ had hypertension; $33.8 \%(30.7 \%$ to $37.1 \%)$ were obese; $21.2 \%$ (18.4\% to $24.2 \%$ ) had hypercholesterolaemia; and $18.7 \%$ had diabetes $(16.2 \%$ to $20.6 \%)$. Men were about half as likely as women to be obese (PR $0.53 ; 0.42$ to 0.67 ). The prevalences of diabetes, hypertension and 
Table 2 Selected sociodemographic characteristics of the survey sample, by sex and collectively*

\begin{tabular}{|c|c|c|c|c|c|c|}
\hline & \multicolumn{2}{|c|}{ Women } & \multicolumn{2}{|l|}{ Men } & \multicolumn{2}{|c|}{ Overall } \\
\hline & $\mathbf{n}$ & Per cent & $\mathbf{n}$ & Per cent & $\mathbf{n}$ & Per cent \\
\hline \multicolumn{7}{|l|}{ Age (years) } \\
\hline $25-44$ & 292 & 39.4 & 158 & 36.2 & 450 & 38.2 \\
\hline $45-64$ & 310 & 41.4 & 206 & 44.0 & 516 & 42.4 \\
\hline 65 and older & 162 & 19.2 & 106 & 19.8 & 268 & 19.4 \\
\hline \multicolumn{7}{|l|}{ Level of education } \\
\hline Less than secondary school & 150 & 18.1 & 82 & 14.0 & 232 & 16.6 \\
\hline Secondary school completed & 296 & 40.9 & 211 & 47.3 & 507 & 43.3 \\
\hline Technical, trade or teacher education & 123 & 16.1 & 80 & 16.7 & 203 & 16.3 \\
\hline University education & 195 & 24.9 & 97 & 22.0 & 292 & 23.8 \\
\hline \multicolumn{7}{|l|}{ Occupational category } \\
\hline Routine/manual & 123 & 15.1 & 185 & 39.1 & 308 & 24.1 \\
\hline Intermediate & 256 & 33.7 & 93 & 17.6 & 349 & 27.6 \\
\hline Professional & 144 & 18.2 & 78 & 19.2 & 222 & 18.6 \\
\hline Not in employment, not retired $†$ & 152 & 21.5 & 49 & 10.3 & 201 & 17.3 \\
\hline Occupation code unavailable $\ddagger$ & 89 & 11.5 & 65 & 14.0 & 154 & 12.4 \\
\hline Total & 764 & 100 & 470 & 100 & 1234 & 100 \\
\hline
\end{tabular}

*Percentages are weighted to compensate for unequal probabilities of selection (selecting one individual from household) and for non-response.

†Includes people on maternity or sick leave $(n=6)$; people looking for work $(n=85)$; home duties $(n=74)$; students $(n=8)$; incapacitated people $(n=28)$.

ҒIncludes people who reported occupation, but that occupation was not listed in Barbados Standard Occupational Classification (BARSOC) coding, as well as retired people who did not report main lifetime occupation.

hypercholesterolaemia were all lower in men; however, the $95 \%$ CIs on the PRs all included 1, compatible with no difference in the underlying population.
Prevalence and age-specific patterns of risk factors

Table 4 shows the distribution of diabetes, hypertension and associated risk factors stratified by age. The

Table 3 Sex-specific and overall prevalence of diabetes, hypertension and associated risk factors in the adult Barbadian population, with age-adjusted prevalence ratios (PRs) for men versus women

\begin{tabular}{|c|c|c|c|}
\hline & Women & Men & Overall \\
\hline \multicolumn{4}{|l|}{ Current tobacco use } \\
\hline Prevalence (\%) $(95 \% \mathrm{Cl})$ & 3.7 (2.3 to 6.1$)$ & 15.5 (11.9 to 20.0$)$ & $9.2(7.2$ to 11.7$)$ \\
\hline PR $(95 \% \mathrm{Cl})$ & $1.00^{*}$ & 4.08 (2.48 to 6.69$)$ & - \\
\hline \multicolumn{4}{|c|}{ Heavy episodic alcohol consumption } \\
\hline Prevalence (\%) $(95 \% \mathrm{Cl})$ & 5.4 (3.2 to 8.8$)$ & 25.4 (21.0 to 30.3$)$ & $14.5(12.0$ to 17.4$)$ \\
\hline $\mathrm{PR}(95 \% \mathrm{Cl})$ & $1.00^{*}$ & 4.55 (2.70 to 7.58$)$ & - \\
\hline \multicolumn{4}{|c|}{ Inadequate fruit and vegetable intake } \\
\hline Prevalence (\%) (95\% Cl) & 88.5 (85.1 to 91.2$)$ & 91.8 (87.0 to 95.0$)$ & $90.0(87.0$ to 92.4$)$ \\
\hline PR $(95 \% \mathrm{Cl})$ & $1.00^{*}$ & 1.39 (0.87 to 2.23$)$ & - \\
\hline \multicolumn{4}{|l|}{ Physical inactivity } \\
\hline Prevalence (\%) $(95 \% \mathrm{Cl})$ & $67.2(63.1$ to 71.1$)$ & 30.0 (24.6 to 36.1$)$ & $49.9(46.1$ to 53.7$)$ \\
\hline PR $(95 \% \mathrm{Cl})$ & $1.00^{*}$ & 0.47 (0.39 to 0.57$)$ & - \\
\hline \multicolumn{4}{|l|}{ Obesity } \\
\hline Prevalence (\%) (95\% Cl) & 43.4 (39.5 to 47.3$)$ & 23.4 (18.9 to 28.5$)$ & $33.8(30.7$ to 37.1$)$ \\
\hline $\mathrm{PR}(95 \% \mathrm{Cl})$ & $1.00^{*}$ & 0.53 (0.42 to 0.67$)$ & - \\
\hline \multicolumn{4}{|l|}{ Hypercholesterolaemia } \\
\hline Prevalence (\%) $(95 \% \mathrm{Cl})$ & $22.9(19.1$ to 27.1$)$ & 19.3 (15.1 to 24.2$)$ & $21.2(18.4$ to 24.2$)$ \\
\hline PR $(95 \% \mathrm{Cl})$ & $1.00^{*}$ & $0.84(0.62$ to 1.13$)$ & - \\
\hline \multicolumn{4}{|l|}{ Hypertension } \\
\hline Prevalence (\%) $(95 \% \mathrm{Cl})$ & 44.0 (38.8 to 49.2$)$ & 36.9 (30.9 to 43.3$)$ & 40.7 (36.5 to 44.9$)$ \\
\hline $\mathrm{PR}(95 \% \mathrm{Cl})$ & $1.00^{*}$ & 0.89 (0.79 to 1.02$)$ & - \\
\hline \multicolumn{4}{|l|}{ Diabetes } \\
\hline Prevalence (\%) $(95 \% \mathrm{Cl})$ & 21.0 (18.2 to 24.2$)$ & 15.9 (12.0 to 20.8$)$ & $18.7(16.2$ to 21.4$)$ \\
\hline $\mathrm{PR}(95 \% \mathrm{Cl})$ & $1.00^{*}$ & $0.83(0.65$ to 1.05$)$ & - \\
\hline
\end{tabular}


Table 4 Prevalence and adjusted prevalence ratios (PRs) of diabetes, hypertension and associated risk factors by age group in the adult Barbadian population

\section{Age group \\ 25-44 years}

45-64 years

65+years

\section{Current tobacco use}

Women

Prevalence (\%) $(95 \% \mathrm{Cl})$

PR $(95 \% \mathrm{Cl})$

Men

Prevalence (\%) $(95 \% \mathrm{Cl})$

PR $(95 \% \mathrm{Cl})$

Total

Prevalence (\%) $(95 \% \mathrm{Cl})$

PR $(95 \% \mathrm{Cl})$

Heavy episodic alcohol consumption

Women

Prevalence (\%) $(95 \% \mathrm{Cl})$

PR $(95 \% \mathrm{Cl})$

Men

Prevalence (\%) $(95 \% \mathrm{Cl})$ PR $(95 \% \mathrm{Cl})$

Total

Prevalence (\%) $(95 \% \mathrm{Cl})$

PR $(95 \% \mathrm{Cl})$

Inadequate fruit and vegetable intake

Women

Prevalence (\%) $(95 \% \mathrm{Cl})$

PR $(95 \% \mathrm{Cl})$

Men

Prevalence (\%) $(95 \% \mathrm{Cl})$ PR $(95 \% \mathrm{Cl})$

Total

Prevalence (\%) $(95 \% \mathrm{CI})$

PR $(95 \% \mathrm{Cl})$

Physical inactivity

Women

Prevalence (\%) $(95 \% \mathrm{CI})$

PR $(95 \% \mathrm{Cl})$

Men

Prevalence (\%) $(95 \% \mathrm{Cl})$

PR $(95 \% \mathrm{Cl})$

Total

Prevalence (\%) $(95 \% \mathrm{CI})$

PR $(95 \%$ Cl)

Obesity

Women

Prevalence (\%) $(95 \% \mathrm{Cl})$

PR $(95 \% \mathrm{Cl})$

Men

Prevalence (\%) $(95 \% \mathrm{Cl})$ PR $(95 \% \mathrm{Cl})$

Total

Prevalence (\%) (95\% CI)

PR $(95 \% \mathrm{Cl})$

Hypercholesterolaemia

Women

Prevalence (\%) $(95 \% \mathrm{CI})$

PR $(95 \% \mathrm{Cl})$

Men

Prevalence (\%) $(95 \% \mathrm{Cl})$

PR $(95 \% \mathrm{Cl})$
4.3 (1.9 to 9.3$)$

1.00 *

20.8 (14.4 to 29.2$)$

$1.00^{*}$

12.2 (8.8 to 16.7$)$

$1.00^{*}$

$8.5(4.4$ to 15.9$)$
$1.00^{*}$

33.2 (24.6 to 43.0$)$

1.00 *

20.0 (15.1 to 26.0$)$

$1.00^{*}$

90.2 (85.6 to 93.5$)$

1.00 *

91.6 (84.5 to 95.6$)$

$1.00^{*}$

2.7 (1.4 to 5.4 )

$0.64(0.22$ to 1.84$)$

13.4 (9.2 to 19.1$)$

0.64 (0.40 to 1.04 )

7.8 (5.6 to 10.8 )

0.64 (0.42 to 0.98$)$

3.4 (2.1 to 5.5$)$

$0.40(0.19$ to 0.85$)$

23.4 (17.5 to 30.5$)$

0.70 (0.47 to 1.07$)$

12.9 (10 to 16.5$)$

0.65 (0.45 to 0.94$)$

88.8 (83.8 to 92.4$)$

0.87 (0.5 to 1.5$)$

92.5 (86.9 to 95.8$)$

$1.12(0.66$ to 1.88$)$

90.5 (87.4 to 92.9$)$

0.96 (0.66 to 1.41$)$

90.9 (86.4 to 94$)$

$1.00^{*}$

63.6 (56.5 to 70.19$)$

$1.00^{*}$

62.6 (55.19 to 69.4$)$

0.98 (0.84 to 1.16$)$

35.4 (26.63 to 45.24$)$

2.00 (1.07 to 3.72 )

49.6 (42.79 to 56.48 )

1.11 (0.95 to 1.3 )

42.7 (37 to 48.7 )

0.93 (0.74 to 1.17$)$

25.7 (19.1 to 33.6)

1.06 (0.65 to 1.74$)$

34.6 (29.6 to 40$)$

0.97 (0.76 to 1.22$)$

$1.00^{*}$

27.3 (22.3 to 33.0$)$

$1.76(1.23$ to 2.53$)$

$1.00^{*}$

22.2 (15.3 to 31.3 )

1.27 (0.44 to 0.69$)$
4.4 (1.8 to 10.4$)$

1.02 (0.3 to 3.46$)$

5.3 (2.4 to 11.5 )

0.26 (0.1 to 0.62$)$

4.7 (2.6 to 8.6$)$

0.42 (0.23 to 0.77 )

2.2 (0.7 to 7$)$

$0.26(0.07$ to 0.96$)$

8.6 (4.4 to 16$)$

$0.26(0.12$ to 0.54$)$

4.8 (2.8 to 8.1$)$

0.26 (0.15 to 0.47$)$

83.9 (75 to 90.1 )

0.61 (0.34 to 1.08$)$

91.0 (80.2 to 96.2$)$

0.94 (0.32 to 2.78$)$

86.8 (80 to 91.5 )

0.70 (0.4 to 1.23$)$

83.0 (76.02 to 88.24$)$ 1.31 (1.15 to 1.5$)$

53.7 (40.33 to 66.47 ) 3.09 (1.72 to 5.53$)$

71.1 (63.3 to 77.77 )

1.47 (1.26 to 1.72 )

39.1 (30.6 to 48.2$)$

0.85 (0.65 to 1.12$)$

15.5 (8.8 to 26 )

0.64 (0.35 to 1.2$)$

29.4 (23.7 to 35.8 )

0.80 (0.62 to 1.04$)$

31.1 (23.2 to 40.3 )

2.01 (1.29 to 3.11$)$

17.2 (10.0 to 28.0 )

0.98 (0.96 to 0.48 ) 
Table 4 Continued

\begin{tabular}{|c|c|c|c|}
\hline & \multicolumn{3}{|l|}{ Age group } \\
\hline & 25-44 years & 45-64 years & $65+$ years \\
\hline \multicolumn{4}{|l|}{$\overline{\text { Total }}$} \\
\hline Prevalence (\%) $(95 \% \mathrm{Cl})$ & 16.5 (12.7 to 21.2$)$ & 24.9 (20.7 to 29.6$)$ & 25.2 (19.9 to 31.5$)$ \\
\hline PR $(95 \% \mathrm{Cl})$ & $1.00^{*}$ & 1.52 (1.12 to 2.06$)$ & $1.53(1.08$ to 2.17$)$ \\
\hline \multicolumn{4}{|l|}{ Hypertension } \\
\hline \multicolumn{4}{|l|}{ Women } \\
\hline Prevalence (\%) $(95 \% \mathrm{Cl})$ & $16.2(11.2$ to 22.7$)$ & 56.5 (49.3 to 63.5$)$ & 80.9 (73.0 to 86.9 ) \\
\hline PR $(95 \% \mathrm{Cl})$ & $1.00^{*}$ & 3.50 (2.51 to 4.87$)$ & 5.01 (3.48 to 7.22$)$ \\
\hline \multicolumn{4}{|l|}{ Men } \\
\hline Prevalence $(\%)(95 \% \mathrm{Cl})$ & 14.1 (8.8 to 21.9$)$ & 48.9 (40.2 to 57.6$)$ & 74.3 (63.8 to 82.6$)$ \\
\hline PR $(95 \% \mathrm{Cl})$ & $1.00^{*}$ & 3.47 (2.16 to 5.56$)$ & 5.27 (3.26 to 8.52$)$ \\
\hline \multicolumn{4}{|l|}{ Total } \\
\hline Prevalence (\%) $(95 \% \mathrm{Cl})$ & $15.2(11.3$ to 20.0$)$ & 52.9 (47.4 to 58.3$)$ & 78.2 (71.8 to 83.5$)$ \\
\hline PR $(95 \% \mathrm{Cl})$ & $1.00^{*}$ & 3.49 (2.66 to 4.58$)$ & $5.10(3.85$ to 6.76$)$ \\
\hline \multicolumn{4}{|l|}{ Diabetes } \\
\hline \multicolumn{4}{|l|}{ Women } \\
\hline Prevalence (\%) $(95 \% \mathrm{Cl})$ & 6.6 (3.7 to 11.3$)$ & 23.0 (18.1 to 28.8$)$ & 48.0 (37.6 to 58.7$)$ \\
\hline PR $(95 \% \mathrm{Cl})$ & $1.00^{*}$ & 3.51 (1.82 to 6.8$)$ & 7.32 (3.87 to 13.87 ) \\
\hline \multicolumn{4}{|l|}{ Men } \\
\hline Prevalence (\%) $(95 \% \mathrm{Cl})$ & 1.5 (0.4 to 4.6$)$ & $21.2(14.5$ to 30.0$)$ & 42.4 (32.1 to 53.3 ) \\
\hline PR $(95 \% \mathrm{Cl})$ & $1.00^{*}$ & 14.60 (4.53 to 47.02$)$ & 29.11 (8.55 to 99.14$)$ \\
\hline \multicolumn{4}{|l|}{ Total } \\
\hline Prevalence (\%) $(95 \% \mathrm{Cl})$ & $4.2(2.5$ to 6.9$)$ & 22.2 (17.7 to 27.3$)$ & 45.7 (38.2 to 53.4 ) \\
\hline PR $(95 \% \mathrm{Cl})$ & $1.00^{*}$ & 5.31 (2.90 to 9.70$)$ & $10.82(6.23$ to 19.00$)$ \\
\hline
\end{tabular}

prevalence of current tobacco use and heavy episodic alcohol consumption decreased in older age groups compared with the youngest, while inactivity increased. The PRs for tobacco use were 0.64 (0.42 to 0.98$)$ in 4564 -year olds and 0.42 (0.23 to 0.77) in over 65s. For heavy episodic alcohol consumption, the PRs were 0.65 (0.45 to 0.94$)$ and $0.26(0.15$ to 0.47$)$ in $45-64$-year olds and over 65s, respectively. The PR for inactivity was 1.47 (1.26 to 1.72$)$ in the over $65 \mathrm{~s}$. Inadequate fruit and vegetable intake was similar across all age groups. As expected, the prevalence of diabetes, hypertension and hypercholesterolaemia increased with age. Obesity, however, remained constant across all age groups for both men and women.

\section{Prevalence and patterns of risk factors by maximum level} of educational attainment

Table 5 shows the distribution of diabetes, hypertension and associated risk factors stratified by maximum level of education attained. Among men, tobacco smoking was less common in the group with the most education (university education) versus the least (less than secondary school; PR 0.18 ; $95 \%$ CI 0.05 to 0.58 ). The PRs for tobacco smoking in men decreased across all education groups relative to the lowest, but this was not statistically significant in the second and third groups. Among women, inadequate fruit and vegetable intake and physical inactivity were less common in groups with more education, compared with those with the least education. In those with a level 3 (technical, trade or teacher) and level 4 (university) education, the PRs for inadequate fruit and vegetable intake were 0.33 (0.13 to 0.82 ) and 0.24 (0.1 to 0.61$)$, respectively, and the PRs for physical inactivity were 0.84 (0.72 to 0.99 ) and 0.75 (0.61 to 0.91 ), respectively. The prevalence of obesity and hypertension did not vary by education level. There was some variation by educational attainment for diabetes and hypercholesterolaemia, but only in women: those with a university education being less likely to have diabetes (PR $0.58 ; 0.36$ to 0.95 ) and hypercholesterolaemia (PR $0.62 ; 0.4$ to 0.96 ) than those who did not complete secondary school.

\section{Prevalence and patterns of risk factors by occupational grade}

Table 6 shows the distribution of diabetes, hypertension and associated risk factors stratified by occupation grade. In general, occupation was not significantly related to the prevalence of these conditions and their risk factors. There were, however, two exceptions. Among men, tobacco smoking was less common in those with a professional occupation compared with those with a routine/manual occupation (PR 0.39; 0.16 to 0.96 ). In women, hypercholesterolaemia was less common in those with a professional occupation compared with those with a routine/manual occupation (PR 0.6; 0.36 to $0.94)$. 
Table 5 Prevalence and age-adjusted prevalence ratios (PRs) of diabetes, hypertension and associated risk factors by education level in the adult Barbadian population

Level 1: Less than Level 2: Secondary Level 3: Technical, trade Level 4: University secondary school school completed or teacher education education

\section{Women}

Current tobacco use

Prevalence (\%) $(95 \% \mathrm{Cl}) \quad 4.4(2.1$ to 8.7$)$

PR $(95 \% \mathrm{Cl})$

$1.00^{*}$

Men

Prevalence $(\%)(95 \% \mathrm{Cl}) \quad 19.8(11.1$ to 32.9$)$

PR $(95 \% \mathrm{Cl})$

Total

Prevalence (\%) (95\% Cl) 10.4 (6.9 to 15.2$)$

PR $(95 \% \mathrm{Cl}) \quad 1.00^{*}$

Heavy episodic alcohol consumption

Women

Prevalence $(\%)(95 \% \mathrm{Cl}) \quad 3.3(1.1$ to 9.8$)$

PR $(95 \% \mathrm{Cl})$

$1.00^{*}$

Men

Prevalence (\%) $(95 \% \mathrm{Cl}) \quad 18.2(11.1$ to 28.4$)$

PR $(95 \% \mathrm{Cl})$

$1.00^{*}$

Total

Prevalence (\%) $(95 \% \mathrm{Cl}) \quad 9.0(6.0$ to 13.3$)$

PR $(95 \% \mathrm{Cl}) \quad 1.00^{*}$

Inadequate fruit and vegetable intake

Women

Prevalence (\%) $(95 \% \mathrm{Cl}) \quad 92.9(84.7$ to 96.8$)$ PR $(95 \% \mathrm{Cl})$

$1.00^{*}$

Men

Prevalence (\%) $(95 \% \mathrm{Cl}) \quad 87.0(71.8$ to 94.6$)$ PR $(95 \% \mathrm{Cl})$

Total

Prevalence $(\%)(95 \% \mathrm{Cl}) \quad 90.7$ (83.6 to 94.9)

PR $(95 \% \mathrm{Cl})$

Physical inactivity

Women

$\begin{array}{ll}\text { Prevalence }(\%) & (95 \% \mathrm{Cl}) \quad 83.2(74.1 \text { to } 89.5) \\ \text { PR }(95 \% \mathrm{Cl}) & 1.00^{*}\end{array}$ PR $(95 \% \mathrm{Cl})$

Men

Prevalence (\%) $(95 \% \mathrm{Cl}) \quad 43.9$ (30.8 to 57.8$)$ PR $(95 \% \mathrm{Cl})$

Total

Prevalence $(\%)(95 \% \mathrm{Cl}) \quad 68.0(58.4$ to 76.3$)$

PR $(95 \% \mathrm{CI})$

$1.00^{*}$

Obesity

Women

Prevalence $(\%)(95 \% \mathrm{Cl}) \quad 34.7$ (28.3 to 41.6$)$

PR $(95 \% \mathrm{Cl})$

Men

Prevalence (\%) (95\% Cl) 19.2 (10.3 to 33)

PR $(95 \% \mathrm{Cl})$

Total

Prevalence (\%) $(95 \% \mathrm{Cl}) \quad 28.6(23.1$ to 34.8$)$

PR $(95 \% \mathrm{Cl})$

Hypercholesterolaemia

Women

Prevalence (\%) $(95 \% \mathrm{Cl}) \quad 34.1$ (25.1 to 44.4$)$

PR $(95 \% \mathrm{Cl})$

$1.00^{*}$

Men

Prevalence (\%) $(95 \% \mathrm{Cl}) \quad 13.13(6.4$ to 25$)$

PR $(95 \% \mathrm{Cl})$

$\begin{array}{cc}4.1(1.9 \text { to } 8.5) & 3.1(1.2 \text { to } 7.7) \\ 0.91(0.29 \text { to } 2.91) & 0.65(0.19 \text { to } 2.19)\end{array}$

18.4 (13 to 25.3$) \quad 16.4$ (8.4 to 29.5$)$

0.55 (0.3 to 1.02$) \quad 0.49(0.22$ to 1.08$)$

11.3 (8.2 to 15.3$) \quad 9.8$ (5.3 to 17.6$)$

0.60 (0.35 to 1.03$) \quad 0.52(0.24$ to 1.1$)$

7.1 (3.2 to 14.9$) \quad 2.9$ (1.2 to 7.2$)$

1.32 (0.39 to 4.43$) \quad 0.51$ (0.1 to 2.55$)$

30.7 (23.7 to 38.6$) \quad 28.4$ (15.8 to 45.6$)$

1.15 (0.61 to 2.17$) \quad 1.07$ (0.49 to 2.33$)$

18.8 (14.2 to 24.7$) \quad 15.5$ (8.6 to 26.5$)$

1.17 (0.65 to 2.12$) \quad 0.99(0.5$ to 1.97$)$

92.9 (89.4 to 95.3$) \quad 83.3$ (69.8 to 91.5$)$

$0.73(0.29$ to 1.81$) \quad 0.33(0.13$ to 0.82$)$

96.1 (91.6 to 98.2) $\quad 85.1$ (70.2 to 93.3)

3.52 (1.05 to 11.83$) \quad 0.93$ (0.32 to 2.69$)$

94.5 (91.8 to 96.4$) \quad 84.2$ (73.6 to 91.1$)$

$1.35(0.61$ to 2.96$) \quad 0.48(0.22$ to 1.04$)$

68.0 (57.2 to 77.2$)$

0.84 (0.72 to 0.99 )

$65.9(59.3$ to 71.9$)$
$0.86(0.74$ to 1.01$)$

21.5 (10.6 to 38.6$)$

30.6 (23.6 to 38.6)

1.02 (0.69 to 1.51$)$

0.77 (0.38 to 1.57 )

48.1 (43 to 53.3 )

44.5 (34.1 to 55.5)

0.90 (0.79 to 1.03$)$

0.83 (0.7 to 0.99 )

49.8 (43.2 to 56.5$)$

40.7 (29.8 to 52.6)

1.41 (1.08 to 1.84 )

1.14 (0.8 to 1.62$)$

26.6 (19.7 to 34.9)

1.21 (0.6 to 2.45 )

22.2 (12.7 to 36.1$)$

1.01 (0.48 to 2.13 )

37.8 (32.4 to 43.6 )

31.2 (23.8 to 39.8 )

1.34 (1.02 to 1.76$)$

1.11 (0.81 to 1.52$)$

23.9 (17.7 to 31.4$)$

19.4 (11.5 to 30.7$)$

0.81 (0.53 to 1.23 )

0.69 (0.38 to 1.25$)$

21.39 (14.7 to 30.1$)$ 1.69 (0.77 to 3.69$)$
3.2 (0.8 to 11.4$)$

0.66 (0.21 to 2.02$)$

5.7 (2.3 to 13.7$)$

0.18 (0.05 to 0.58$)$

4.2 (1.7 to 10.1$)$

0.25 (0.09 to 0.69 )

5.8 (3.0 to 10.9$)$

0.85 (0.25 to 2.89$)$

15.2 (8.3 to 26.4 )

0.59 (0.26 to 1.31$)$

9.7 (6.2 to 14.9$)$

0.66 (0.36 to 1.2$)$

81.9 (75.4 to 86.9$)$ 0.24 (0.1 to 0.61 )

90.9 (76.4 to 96.8$)$ 1.48 (0.37 to 5.9$)$

85.6 (79.2 to 90.3$)$ 0.50 (0.24 to 1.07$)$

57.1 (49.1 to 64.7$)$

0.75 (0.61 to 0.91$)$

27.9 (18.9 to 39.1$)$ 0.89 (0.58 to 1.35$)$

44.9 (39.2 to 50.8$)$ 0.80 (0.68 to 0.95$)$

41.0 (32.3 to 50.2$)$ $1.12(0.78$ to 1.61$)$

19.6 (12.6 to 29.4$)$

0.87 (0.41 to 1.85$)$

31.7 (25.7 to 38.5$)$ 1.05 (0.78 to 1.43 )

16.1 (11.7 to 21.8$)$ 0.62 (0.4 to 0.96$)$

17.46 (10.6 to 27.4 ) 1.34 (0.52 to 3.48$)$ 
Table 5 Continued

\begin{tabular}{|c|c|c|c|c|}
\hline & $\begin{array}{l}\text { Level 1: Less than } \\
\text { secondary school }\end{array}$ & $\begin{array}{l}\text { Level 2: Secondary } \\
\text { school completed }\end{array}$ & $\begin{array}{l}\text { Level 3: Technical, trade } \\
\text { or teacher education }\end{array}$ & $\begin{array}{l}\text { Level 4: University } \\
\text { education }\end{array}$ \\
\hline \multicolumn{5}{|l|}{ Total } \\
\hline Prevalence (\%) (95\% Cl) & 25.54 (18.4 to 34.3 ) & 22.66 (18.4 to 27.6$)$ & 19.98 (13.3 to 28.8$)$ & 16.68 (12.5 to 21.9$)$ \\
\hline $\mathrm{PR}(95 \% \mathrm{Cl})$ & $1.00^{*}$ & 0.99 (0.66 to 1.48$)$ & 0.90 (0.54 to 1.52$)$ & 0.75 (0.47 to 1.22$)$ \\
\hline \multicolumn{5}{|l|}{ Hypertension } \\
\hline \multicolumn{5}{|l|}{ Women } \\
\hline Prevalence (\%) (95\% Cl) & 67.6 (57.9 to 75.9$)$ & 44.9 (36.5 to 53.6$)$ & 41.2 (31.2 to 52$)$ & 28.1 (21.3 to 35.9 ) \\
\hline $\mathrm{PR}(95 \% \mathrm{Cl})$ & $1.00^{*}$ & 1.07 (0.9 to 1.26$)$ & $1.00(0.84$ to 1.18$)$ & 0.92 (0.66 to 1.27$)$ \\
\hline \multicolumn{5}{|l|}{ Men } \\
\hline Prevalence (\%) (95\% Cl) & 65.9 (52.4 to 77.3$)$ & 32.9 (25.3 to 41.5$)$ & 23.8 (15.3 to 35.1$)$ & 40.3 (27.6 to 54.5 ) \\
\hline PR $(95 \% \mathrm{Cl})$ & $1.00^{*}$ & 0.85 (0.66 to 1.08$)$ & 0.65 (0.41 to 1.02$)$ & 0.89 (0.66 to 1.2$)$ \\
\hline \multicolumn{5}{|l|}{ Total } \\
\hline Prevalence (\%) (95\% Cl) & $66.9(58.5$ to 74.4$)$ & 38.8 (33.1 to 44.8$)$ & 32.4 (25.0 to 40.9 ) & 33.2 (26.5 to 40.6$)$ \\
\hline $\operatorname{PR}(95 \% \mathrm{Cl})$ & $1.00^{*}$ & 0.99 (0.85 to 1.16$)$ & $0.88(0.73$ to 1.06$)$ & 0.94 (0.76 to 1.16$)$ \\
\hline \multicolumn{5}{|l|}{ Diabetes } \\
\hline \multicolumn{5}{|l|}{ Women } \\
\hline Prevalence (\%) (95\% Cl) & 43.0 (34.9 to 51.6$)$ & 18.0 (13.2 to 24.0$)$ & 20.3 (13.2 to 30.0$)$ & $10.8(6.7$ to 17.0$)$ \\
\hline $\mathrm{PR}(95 \% \mathrm{Cl})$ & $1.00^{*}$ & $0.74(0.5$ to 1.1$)$ & 0.76 (0.52 to 1.12$)$ & 0.58 (0.36 to 0.95$)$ \\
\hline \multicolumn{5}{|l|}{ Men } \\
\hline Prevalence (\%) (95\% Cl) & 25.0 (16.8 to 35.3$)$ & $15.0(9.9$ to 22.1$)$ & $13.0(6.5$ to 24.4$)$ & 14.8 (8.5 to 24.6$)$ \\
\hline PR $(95 \% \mathrm{Cl})$ & $1.00^{*}$ & 1.34 (0.82 to 2.17$)$ & $1.23(0.70$ to 2.17$)$ & 1.29 (0.69 to 2.40$)$ \\
\hline \multicolumn{5}{|l|}{ Total } \\
\hline Prevalence (\%) (95\% Cl) & $35.9(29.2$ to 43.1$)$ & 16.5 (13.3 to 20.4$)$ & 16.7 (10.8 to 25.1$)$ & 12.5 (8.7 to 17.7$)$ \\
\hline PR $(95 \% \mathrm{Cl})$ & $1.00^{*}$ & 0.91 (0.69 to 1.19$)$ & $0.88(0.62$ to 1.25$)$ & 0.81 (0.56 to 1.19$)$ \\
\hline
\end{tabular}

\section{DISCUSSION}

This study offers insight into the social distribution of diabetes, hypertension and related risk factors in a Caribbean population. In Barbados, sex appears to be an important determinant of NCD risk, with obesity and physical inactivity more common in women, and tobacco use and heavy episodic alcohol consumption more common in men. We found some evidence of differences in risk by education level, but these were sexspecific: in women, higher educational attainment was associated with reduced prevalence of inadequate fruit and vegetable intake, physical inactivity, diabetes and hypercholesterolaemia. However, with the exception of tobacco use, we observed no differences in risk factor prevalence by education in men. Occupation was a less important determinant of NCD risk: in men only higher occupational grade was associated with less tobacco use and in women with lower total cholesterol.

The sex differences we observed for the prevalence of tobacco smoking and heavy episodic alcohol consumption reflect global patterns, which show that men are more likely to engage in these behaviours. ${ }^{18} 19$ Our findings were also consistent with global trends in the socioeconomic distribution of smoking. In men, tobacco smoking is concentrated in lower socioeconomic groups in developed and developing countries, while for women, there is no clear pattern and trends differ by setting. ${ }^{720}$ We found no association between heavy episodic alcohol consumption and either education or occupation. This finding is not unusual, as social variation in alcohol consumption is not consistently observed, and is thought to be influenced more heavily by culture than development status. ${ }^{21}$

Studies from the UK, ${ }^{22}$ the European region ${ }^{23}$ and 52 countries taking part in the World Health Survey ${ }^{24}$ show that low fruit and vegetable consumption is more prevalent in lower socioeconomic groups. In contrast, our analysis found little socioeconomic variation in low fruit and vegetable consumption, apart from a lower prevalence in women with more education. This is likely to be due to the ubiquitous nature of this risk factor in our population: its prevalence was over $80 \%$ in all groups, regardless of sex, age, education or occupation.

Our physical activity data are consistent with a recent review of global physical activity patterns, which found that, on the whole, men are more physically active than women, and older people are less active than younger people. ${ }^{25}$ We found that higher levels of education were associated with a lower prevalence of inactivity in women, but not men. Globally, overall physical activity is not consistently associated with socioeconomic position, and it has been suggested that this is due to contrasting socioeconomic patterns for leisure time and occupational activity. ${ }^{26}$ Our analysis did not differentiate between these types of activity, and this may have masked more complex relationships between socioeconomic position and different physical activity components. 
Table 6 Prevalence and age-adjusted prevalence ratios (PRs) of diabetes, hypertension and associated risk factors by occupational grade in the adult Barbadian population

\begin{tabular}{|c|c|c|c|}
\hline & Routine/manual & Intermediate & Professional \\
\hline \multicolumn{4}{|l|}{ Current tobacco use } \\
\hline \multicolumn{4}{|l|}{ Women } \\
\hline Prevalence (\%) (95\% Cl) & 4.8 (1.4 to 15.5$)$ & $2.0(0.9$ to 4.4$)$ & $7.4(2.8$ to 18.1$)$ \\
\hline $\mathrm{PR}(95 \% \mathrm{Cl})$ & $1.00^{*}$ & 0.37 (0.08 to 1.64$)$ & $1.46(0.32$ to 6.71$)$ \\
\hline \multicolumn{4}{|l|}{ Men } \\
\hline Prevalence (\%) (95\% Cl) & 18.1 (12.4 to 25.7$)$ & $24.4(13.5$ to 40$)$ & $1.1(0.1$ to 8.4$)$ \\
\hline $\mathrm{PR}(95 \% \mathrm{Cl})$ & $1.00^{*}$ & $1.28(0.67$ to 2.45$)$ & 0.06 (0.01 to 0.52$)$ \\
\hline \multicolumn{4}{|l|}{ Total } \\
\hline Prevalence (\%) (95\% Cl) & 14.0 (9.8 to 19.6$)$ & $9.1(5.2$ to 15.4$)$ & 4.5 (1.9 to 10.6$)$ \\
\hline PR $(95 \% \mathrm{Cl})$ & $1.00^{*}$ & $0.98(0.49$ to 1.96$)$ & $0.39(0.16$ to 0.96$)$ \\
\hline \multicolumn{4}{|c|}{ Heavy episodic alcohol consumption } \\
\hline \multicolumn{4}{|c|}{ Women } \\
\hline Prevalence (\%) (95\% Cl) & 5.0 (1.9 to 12.7$)$ & $4.4(1.7$ to 10.6$)$ & 9.3 (4.9 to 16.9$)$ \\
\hline $\mathrm{PR}(95 \% \mathrm{Cl})$ & $1.00^{*}$ & $0.60(0.15$ to 2.41$)$ & $1.38(0.41$ to 4.64$)$ \\
\hline \multicolumn{4}{|l|}{ Men } \\
\hline Prevalence (\%) (95\% Cl) & 24.1 (17.0 to 33.0$)$ & $30.2(18.5$ to 45.1$)$ & $23.2(14.4$ to 35.2$)$ \\
\hline $\mathrm{PR}(95 \% \mathrm{Cl})$ & $1.00^{*}$ & 1.21 (0.65 to 2.27$)$ & 0.98 (0.56 to 1.72$)$ \\
\hline \multicolumn{4}{|l|}{ Total } \\
\hline Prevalence (\%) (95\% Cl) & $18.2(13.1$ to 24.7$)$ & 12.5 (8.1 to 18.9$)$ & $15.6(10.2$ to 23.2$)$ \\
\hline PR $(95 \% \mathrm{Cl})$ & $1.00^{*}$ & $1.08(0.61$ to 1.92$)$ & $1.09(0.67$ to 1.77$)$ \\
\hline \multicolumn{4}{|c|}{ Inadequate fruit and vegetable intake } \\
\hline \multicolumn{4}{|l|}{ Women } \\
\hline Prevalence (\%) (95\% Cl) & 89.1 (78.7 to 94.7$)$ & 86.5 (79.6 to 91.3$)$ & 81.7 (73.7 to 87.7$)$ \\
\hline $\mathrm{PR}(95 \% \mathrm{Cl})$ & $1.00^{*}$ & $0.70(0.32$ to 1.53$)$ & $0.52(0.25$ to 1.12$)$ \\
\hline \multicolumn{4}{|l|}{ Men } \\
\hline Prevalence (\%) (95\% Cl) & 89.4 (81.1 to 94.3$)$ & 91.3 (81.2 to 96.3$)$ & 96.2 (89 to 98.8$)$ \\
\hline $\mathrm{PR}(95 \% \mathrm{Cl})$ & $1.00^{*}$ & $1.23(0.57$ to 2.67$)$ & $2.82(0.81$ to 9.90$)$ \\
\hline \multicolumn{4}{|l|}{ Total } \\
\hline Prevalence (\%) (95\% Cl) & $89.3(83.7$ to 93.1$)$ & 88.0 (81.9 to 92.3$)$ & 88.4 (83 to 92.3 ) \\
\hline PR $(95 \% \mathrm{CI})$ & $1.00^{*}$ & $1.02(0.65$ to 1.61$)$ & $0.97(0.58$ to 1.63$)$ \\
\hline \multicolumn{4}{|l|}{ Physical inactivity } \\
\hline \multicolumn{4}{|l|}{ Women } \\
\hline Prevalence (\%) (95\% Cl) & 67.7 (57.4 to 76.5$)$ & 65.0 (57.4 to 71.9$)$ & $62.5(52.2$ to 71.8$)$ \\
\hline PR $(95 \% \mathrm{CI})$ & $1.00^{*}$ & $0.97(0.83$ to 1.14$)$ & $0.97(0.82$ to 1.15$)$ \\
\hline \multicolumn{4}{|l|}{ Men } \\
\hline Prevalence (\%) (95\% Cl) & $27.8(21.2$ to 35.5$)$ & 33.6 (24.8 to 43.7$)$ & 34.1 (24.3 to 45.3$)$ \\
\hline PR $(95 \% \mathrm{Cl})$ & $1.00^{*}$ & 1.19 (0.92 to 1.54$)$ & $1.23(0.87$ to 1.75$)$ \\
\hline \multicolumn{4}{|l|}{ Total } \\
\hline Prevalence (\%) (95\% Cl) & 40.0 (33.9 to 46.5$)$ & 55.0 (48.6 to 61.3$)$ & 49.3 (41.8 to 56.7$)$ \\
\hline PR $(95 \% \mathrm{Cl})$ & $1.00^{*}$ & $1.02(0.88$ to 1.18$)$ & 1.04 (0.9 to 1.2$)$ \\
\hline \multicolumn{4}{|l|}{ Obesity } \\
\hline \multicolumn{4}{|l|}{ Women } \\
\hline Prevalence (\%) (95\% Cl) & 48.0 (38.8 to 57.4$)$ & 44.8 (38 to 51.9 ) & 40.7 (31.6 to 50.5$)$ \\
\hline $\mathrm{PR}(95 \% \mathrm{Cl})$ & $1.00^{*}$ & $0.85(0.64$ to 1.15$)$ & $0.78(0.55$ to 1.11$)$ \\
\hline Men & & & \\
\hline Prevalence (\%) (95\% Cl) & 21.4 (15.8 to 28.4$)$ & 33.2 (22.6 to 45.9$)$ & 28.1 (15.7 to 45$)$ \\
\hline $\mathrm{PR}(95 \% \mathrm{Cl})$ & $1.00^{*}$ & 1.51 (0.94 to 2.42$)$ & $1.28(0.69$ to 2.36$)$ \\
\hline Total & & & \\
\hline Prevalence (\%) (95\% Cl) & 29.4 (24.3 to 35.1$)$ & 41.0 (34.7 to 47.6$)$ & 34.6 (26.1 to 44.3$)$ \\
\hline $\mathrm{PR}(95 \% \mathrm{Cl})$ & $1.00^{*}$ & $1.07(0.79$ to 1.45$)$ & $0.99(0.69$ to 1.41$)$ \\
\hline Hypercholesterolaemia & & & \\
\hline Women & & & \\
\hline Prevalence (\%) (95\% Cl) & 28.7 (19.7 to 39.9$)$ & 23.8 (17 to 32.2 ) & 13.8 (8.9 to 20.8$)$ \\
\hline PR $(95 \% \mathrm{Cl})$ & $1.00^{*}$ & $0.99(0.63$ to 1.56$)$ & $0.58(0.36$ to 0.94$)$ \\
\hline Men & & & \\
\hline Prevalence (\%) (95\% Cl) & 22.0 (15.4 to 30.5$)$ & $14.2(7.3$ to 25.8$)$ & 15.3 (7.1 to 29.7$)$ \\
\hline PR $(95 \% \mathrm{Cl})$ & $1.00^{*}$ & $0.66(0.29$ to 1.51$)$ & $0.69(0.32$ to 1.46$)$ \\
\hline
\end{tabular}


Table 6 Continued

\begin{tabular}{|c|c|c|c|}
\hline & Routine/manual & Intermediate & Professional \\
\hline \multicolumn{4}{|l|}{ Total } \\
\hline Prevalence (\%) (95\% Cl) & 23.9 (18.5 to 30.4$)$ & 20.8 (15.2 to 27.7$)$ & 14.5 (9.5 to 21.4$)$ \\
\hline PR $(95 \% \mathrm{Cl})$ & $1.00^{*}$ & $0.86(0.57$ to 1.29$)$ & $0.60(0.38$ to 0.94$)$ \\
\hline \multicolumn{4}{|l|}{ Hypertension } \\
\hline \multicolumn{4}{|l|}{ Women } \\
\hline Prevalence (\%) $(95 \% \mathrm{Cl})$ & 56.5 (45.3 to 67.1$)$ & 38.0 (31.2 to 45.2$)$ & $33.0(23.5$ to 44$)$ \\
\hline PR $(95 \% \mathrm{Cl})$ & $1.00^{*}$ & $1.08(0.91$ to 1.28$)$ & $0.90(0.67$ to 1.2$)$ \\
\hline \multicolumn{4}{|l|}{ Men } \\
\hline Prevalence (\%) $(95 \% \mathrm{Cl})$ & 35.1 (26.3 to 45.1$)$ & 35.8 (25.9 to 47.1$)$ & 38.6 (27.9 to 50.4$)$ \\
\hline PR $(95 \% \mathrm{Cl})$ & $1.00^{*}$ & $1.08(0.81$ to 1.45$)$ & $1.06(0.77$ to 1.44$)$ \\
\hline \multicolumn{4}{|l|}{ Total } \\
\hline Prevalence (\%) $(95 \% \mathrm{Cl})$ & 41.7 (34.3 to 49.4$)$ & 37.3 (31.7 to 43.2$)$ & 35.6 (28.4 to 43.4$)$ \\
\hline PR $(95 \% \mathrm{Cl})$ & $1.00^{*}$ & $1.09(0.93$ to 1.27$)$ & $0.97(0.80$ to 1.17$)$ \\
\hline \multicolumn{4}{|l|}{ Diabetes } \\
\hline \multicolumn{4}{|l|}{ Women } \\
\hline Prevalence (\%) $(95 \% \mathrm{Cl})$ & 32.7 (21.6 to 46.2$)$ & 15.7 (11.1 to 21.6$)$ & $17.4(10.7$ to 27.1$)$ \\
\hline PR $(95 \% \mathrm{Cl})$ & $1.00^{*}$ & $0.72(0.48$ to 1.07$)$ & $0.73(0.42$ to 1.29$)$ \\
\hline \multicolumn{4}{|l|}{ Men } \\
\hline Prevalence (\%) $(95 \% \mathrm{Cl})$ & 14.1 (9.0 to 21.5$)$ & 14.5 (7.6 to 26.1$)$ & 17.3 (9.7 to 29.0$)$ \\
\hline PR (95\% Cl) & $1.00^{*}$ & $1.26(0.65$ to 2.45$)$ & $1.39(0.76$ to 2.56$)$ \\
\hline \multicolumn{4}{|l|}{ Total } \\
\hline Prevalence (\%) $(95 \% \mathrm{Cl})$ & $19.6(15.1$ to 25.1$)$ & 15.3 (10.6 to 21.5$)$ & 17.4 (11.5 to 25.2$)$ \\
\hline PR $(95 \% \mathrm{Cl})$ & $1.00^{*}$ & 0.90 (0.58 to 1.39$)$ & 0.98 (0.62 to 1.54$)$ \\
\hline
\end{tabular}

Our findings revealed a high prevalence of obesity in the Barbadian population (33.8\%) relative to the global averages of $10 \%$ in men and $14 \%$ in women. ${ }^{27}$ The level of obesity we found was similar to the USA, where obesity levels are around $35 \%,{ }^{28}$ and were higher than those found in the UK $(26 \%)^{29}$ and Jamaica $(25 \%) \cdot{ }^{30}$ In contrast with global patterns, ${ }^{7}{ }^{28} 31$ we found that obesity prevalence did not increase with age, and did not vary by socioeconomic position.

We found higher levels of hypertension in this population $(40.7 \%)$ than those observed in the $\mathrm{USA}^{32}$ and Jamaica, ${ }^{33}$ where hypertension prevalence is approximately $35 \%$ and $25 \%$, respectively, though not as high as seen in the non-Hispanic black population in the USA $(47.8 \%)$. In developed countries, higher socioeconomic position is consistently associated with lower blood pressure and a lower prevalence of hypertension. ${ }^{34}$ In contrast, we did not observe variation in hypertension prevalence by socioeconomic position. However, this is not unexpected, given the disparate picture of the social distribution of hypertension in the Caribbean. A study carried out in Trinidad and Tobago found that blood pressure was inversely associated with socioeconomic position in terms of income and education, but this relationship was observed only in women. ${ }^{35}$ A Jamaican study found differences in hypertension prevalence by socioeconomic position, though in the opposite directions for men and women: in Jamaican men, hypertension was more common in higher social groups, while the reverse was found in Jamaican women. ${ }^{32}$
The proportion of the Barbadian population affected by diabetes $(18.7 \%)$ is greater than the global average $(8.3 \%)$, as well as national levels in the USA $(9.3 \%)^{4}$ and Jamaica $(7.9 \%),{ }^{30}$ though a formal, age-standardised comparison has not been made. ${ }^{36}$ The prevalence of diabetes in our population was higher in women $(21.0 \%)$ compared with men $(15.9 \%)$. While this difference does not achieve traditional statistical significance (95\% CI on the PR 0.65 to 1.05 ), it is consistent with findings from other studies in the Caribbean. A recently conducted systematic review has described that on average, women in the Caribbean are approximately 1.5 times more likely to have type 2 diabetes than men. ${ }^{37}$ This finding is unusual, given that in most parts of the world, diabetes prevalence is similar in men and women or higher in men, ${ }^{4}$ because at a given level of body mass index men appear to be more susceptible to type 2 diabetes than women. ${ }^{38}$ The reversal of the sex difference in diabetes prevalence that is seen in the Caribbean, with which the results of this study are consistent, is related to much higher prevalences of obesity and physical inactivity in Caribbean women compared with men, ${ }^{37}$ the major risk factors for type 2 diabetes. ${ }^{39}$ Only in women was there evidence that diabetes is more common in those with less education, while worldwide, diabetes prevalence is consistently associated with low socioeconomic position in both developed and developing countries. ${ }^{40} 41$

Previous research has shown that the association between socioeconomic position and cholesterol level is 
inconsistent. Several studies have observed inverse relationships between socioeconomic position and cholesterol levels ${ }^{42}{ }^{43}$; others have reported higher cholesterol levels among those with higher education or higher grade of occupation ${ }^{44}$; and some found no association at all. ${ }^{45}$ In developing countries, direct associations have been found, with higher socioeconomic position associated with higher levels of serum lipids. ${ }^{46}{ }^{47}$ We did not find clear social patterns for total cholesterol, and statistically significant group comparisons were once again limited to women.

Historically, the adoption of high-risk behaviours and the resulting pathophysiological outcomes tends to transition from higher to lower socioeconomic groups as countries develop economically. ${ }^{7}$ Risky behaviours are first adopted by more socially advantaged groups, who tend to abandon them over time. Less socially advantaged groups tend to engage in these behaviours later on in a country's development, and may be less able to change their environment and behaviours due to inadequate resources. The lack of clear patterns for the social distribution of obesity, hypertension and diabetes observed in our study may indicate that Barbados is part way through this classic transition. Although previous research into the social distribution on NCDs and their risk factors is limited in this population, there is some evidence that shows how the distribution of obesity is changing. A study carried out in the 1990s found that obesity was more common in higher socioeconomic groups, ${ }^{48}$ indicating that, over two decades, the social pattern of obesity has changed from primarily affecting higher socioeconomic groups to pervading the whole society. Whether obesity will follow the classic pattern and become more concentrated in less-advantaged groups or whether it will remain widespread in this population is uncertain. Continued surveillance is required to better understand these trends, and those of other risk factors and NCDs.

In 2011, the Rio Political Declaration on Social Determinants of Health reaffirmed international commitment to reducing health inequities by implementing a social determinants of health approach. ${ }^{2}$ Our study demonstrates how population surveillance of NCDs and their risk factors can provide contextspecific information to support these efforts. In the Barbadian population, population-wide strategies are needed to address the high levels of obesity, hypertension, diabetes and related behaviours. However, policymakers and public health professionals should consider the important sex inequalities highlighted by our analysis when designing interventions for this population. Further research is needed to determine what factors underlie these differences by sex, and their implications for designing interventions, for example, how different do interventions for men and women need to be? Future surveys should consider collecting data on absolute and relative wealth, such as income or household possessions.
Our study has a number of strengths and possible limitations. Diabetes, hypertension, obesity and hypercholesterolaemia were assessed by objective measurements, and are therefore not subject to the inherent interviewee bias in subjective questionnaire responses. However, behavioural risk factors, demographic and socioeconomic variables were reported by participants, which may have introduced information bias. The crosssectional design of the study did not allow for examination of temporal relationships. Numbers for some analyses were small, and the associated CIs were wide. The study response rate was relatively low, particularly among young males, which may affect the generalisability of the results. This was addressed by the sample weighting scheme, which ensures that estimates provided by age and sex are generalisable to the adult Barbadian population, at least in terms of age and sex.

In conclusion, our findings reveal different patterns of NCD risk in a developing setting than those commonly seen in developed countries. In the Barbadian population, sex is a strong determinant of behavioural risk factors, and consequent obesity and its related risks. Only in women was higher education related to lower levels of several risk factors. This is in contrast to most developed settings, where markers of socioeconomic position operate similarly across both sexes. Our findings provide important baseline information, which should be considered when policies to reduce health inequities are being implemented. Further population health surveillance and monitoring are needed to determine trends.

Contributors $\mathrm{CH}, \mathrm{IRH}, \mathrm{AH}, \mathrm{TAS}, \mathrm{AMCR}$ and NU conceived and designed the study, and supervised data collection. $\mathrm{CH}$ and IRH performed the statistical analysis. $\mathrm{CH}$ and NU produced the first article draft. All authors critically revised the manuscript, and read and approved the final version.

Funding The project was supported by the Ministry of Health of the Government of Barbados.

\section{Competing interests None declared.}

Ethics approval Research Ethics Committee of the University of the West Indies, Cave Hill/Barbados Ministry of Health.

Provenance and peer review Not commissioned; externally peer reviewed.

Data sharing statement No additional data are available.

Open Access This is an Open Access article distributed in accordance with the Creative Commons Attribution Non Commercial (CC BY-NC 4.0) license, which permits others to distribute, remix, adapt, build upon this work noncommercially, and license their derivative works on different terms, provided the original work is properly cited and the use is non-commercial. See: http:// creativecommons.org/licenses/by-nc/4.0/

\section{REFERENCES}

1. Friel S, Marmot MG. Action on the social determinants of health and health inequities goes global. Annu Rev Public Health 2011;32:225-36.

2. World Health Organization. Rio Political Declaration on Socia Determinants of Health (cited 16 March 2015). http://www.who.int/ sdhconference/declaration/en/

3. World Health Organization. Noncommunicable diseases country profiles 2011. Geneva, Switzerland: World Health Organization, 
2011 (cited 28 November 2014). http://www.who.int/nmh/ publications/ncd profiles report.pdf

4. International Diabetes Federation (cited 28 November 2014]. http:// www.idf.org/

5. Mendis S, Puska P, Norrving B, World Health Organization, World Heart Federation, World Stroke Organization. Global atlas on cardiovascular disease prevention and control. Geneva: World Health Organization in collaboration with the World Heart Federation and the World Stroke Organization, 2011.

6. Adler NE, Stewart J. Preface to the biology of disadvantage: socioeconomic status and health. Ann N Y Acad Sci 2010;1186:1-4

7. Fleischer NL, Diez Roux AV, Hubbard AE. Inequalities in body mass index and smoking behavior in 70 countries: evidence for a social transition in chronic disease risk. Am J Epidemiol 2012;175:167-76.

8. Barbados Statistical Service. Barbados Population and Housing Census. 2010 (cited 27 November 2014). http://www.barstats.gov. $\mathrm{bb} /$ files/documents/PHC_2010_Census_Volume_1.pdf

9. Chief Medical Officer. Annual report of the Chief Medical Officer, 2004-6. Ministry of Health Barbados, August 2010.

10. IMF World Economic Outlook (WEO). Transitions and Tensions, October 2013 (cited 17 February 2015)]. http://www.imf.org/external/ pubs/ft/weo/2013/02/index.htm

11. World Bank Data Country and Lending Groups (cited 26 February 2015). http://data.worldbank.org/about/ country-and-lending-groups\#High_income

12. UN SIDS. Small Islands Bigger Stakes (cited 7 April 2015). http:// unohrlls.org/custom-content/uploads/2013/08/ SIDS-Small-Islands-Bigger-Stakes.pdf

13. Kish L. Survey sampling. New York: John Wiley and Sons, 1965.

14. World Health Organization. WHO STEPS Surveillance Manual: the WHO STEP wise approach to chronic disease risk factor surveillance. The Pan American version. Geneva: World Health Organization, 2005 (cited 3 April 2015). http://www2.paho.org/hq/ dmdocuments/2011/PanAm\%20STEPS\%20risk\%20factor.pdf

15. Barbados Standard Occupational Classification. Government of Barbados, Ministry of Employment, Labour Relations and Community Development (cited 7 April 2015). https://labour.gov.bb/ images/BARSOC.pdf

16. International Labour Organisation. International Standard Classification of Occupations (cited 7 April 2015). http://www.ilo.org/ public/english/bureau/stat/isco/isco88/

17. Besson $\mathrm{H}$, Brage S, Jakes RW, et al. Estimating physical activity energy expenditure, sedentary time, and physical activity intensity by self-report in adults. Am J Clin Nutr 2010;91:106-14.

18. World Health Organization. Gender, women, and the tobacco epidemic (cited 19 February 2015). http://www.who.int/tobacco/ publications/gender/women_tob_epidemic/en/

19. World Health Organization. Alcohol, gender, and drinking problems (cited 13 March 2015). http://www.who.int/substance_abuse/ publications/alcohol gender drinking problems.pdf

20. Hosseinpoor AR, Parker LA, Tursan d'Espaignet E, et al. Social determinants of smoking in low- and middle-income countries: results from the World Health Survey. PLOS ONE 2011;6:e20331.

21. Bloomfield K, Grittner U, Kramer S, et al. Social inequalities in alcoho consumption and alcohol-related problems in the study countries of the EU concerted action 'Gender, Culture and Alcohol Problems: a Multi-national Study'. Alcohol Alcohol Supp/ 2006;41:i26-36.

22. Public Health England: Social and economic inequalities in diet and physical activity (cited 20 February 2015). http://www.noo.org.uk/ uploads/doc/vid_19253_Social_and_economic_inequalities_in_diet_ and physical activity 04.11.13.pdf

23. Giskes $\mathrm{K}$, Avendano $\mathrm{M}$, Brug $\mathrm{J}$, et al. A systematic review of studies on socioeconomic inequalities in dietary intakes associated with weight gain and overweight/obesity conducted among European adults. Obes Rev 2010;11:413-29.

24. Hall JN, Moore S, Harper SB, et al. Global variability in fruit and vegetable consumption. Am J Prev Med 2009;36:402-9.e5.

25. Hallal PC, Andersen LB, Bull FC, et al. Global physical activity levels: surveillance progress, pitfalls, and prospects. Lancet 2012;380:247-57.

26. Beenackers MA, Kamphuis CB, Giskes K, et al. Socioeconomic inequalities in occupational, leisure-time, and transport related physical activity among European adults: a systematic review. Int $J$ Behav Nutr Phys Act 2012;9:116.
27. World Health Organization. Global status report on non-communicable diseases 2010 (cited 10 March 2015). http:// www.who.int $/ \mathrm{nmh} /$ publications/ncd_report_full_en.pdf

28. Ogden $\mathrm{CL}$, Carroll MD, Kit BK, et al. Prevalence of childhood and adult obesity in the United States, 2011-2012. JAMA 2014; 311:806

29. Trends in obesity prevalence: Public Health England Obesity Knowledge and Intelligence team (cited 20 February 2015). http:// www.noo.org.uk/NOO about obesity/trends

30. Cunningham-Myrie C, Younger-Coleman N, Tulloch-Reid M, et al. Diabetes mellitus in Jamaica: sex differences in burden, risk factors, awareness, treatment and control in a developing country. Trop Med Int Health 2013;18:1365-78.

31. NCHS Data Brief, Number 50, December 2010—db50.pdf (cited 20 February 2015). http://www.cdc.gov/nchs/data/databriefs/db50. pdf

32. Mendez MA, Cooper R, Wilks R, et al. Income, education, and blood pressure in adults in Jamaica, a middle-income developing country. Int J Epidemiol 2003;32:400-8.

33. Gillespie CD, Hurvitz KA. Prevalence of hypertension and controlled hypertension-United States, 2007-2010. MMWR Surveill Summ 2013;62(Suppl 3):144-8.

34. Colhoun HM, Hemingway H, Poulter NR. Socio-economic status and blood pressure: an overview analysis. J Hum Hypertens 1998;12:91-110.

35. Gulliford MC, Mahabir D, Rocke B. Socioeconomic inequality in blood pressure and its determinants: cross-sectional data from Trinidad and Tobago. J Hum Hypertens 2004:18:61-70.

36. Cowie CC, Rust KF, Byrd-Holt DD, et al. Prevalence of diabetes and impaired fasting glucose in adults in the U.S. population: National Health And Nutrition Examination Survey 1999-2002. Diabetes Care 2006;29:1263-8.

37. Sobers-Grannum N, Murphy M, Guell C, et al. The importance of gender as a social determinant of diabetes in the Caribbean: a systematic review and meta-analysis. PLOS ONE 2015;10: e0126799.

38. Sattar N. Gender aspects in type 2 diabetes mellitus and cardiometabolic risk. Best Pract Res Clin Endocrinol Metab 2013;27:501-7.

39. World Health Organization: Diabetes (cited 13 March 2015). http:// www.who.int/mediacentre/factsheets/fs312/en/

40. Agardh E, Allebeck P, Hallqvist J, et al. Type 2 diabetes incidence and socio-economic position: a systematic review and meta-analysis. Int J Epidemiol 2011:40:804-18.

41. Espelt A, Borrell C, Roskam AJ, et al. Socioeconomic inequalities in diabetes mellitus across Europe at the beginning of the 21st century. Diabetologia 2008:51:1971-9.

42. Shohaimi S, Boekholdt MS, Luben R, et al. Distribution of lipid parameters according to different socio-economic indicators- the EPIC-Norfolk prospective population study. BMC Public Health 2014;14:782.

43. Benetou V, Chloptsios Y, Zavitsanos X, et al. Total cholesterol and $\mathrm{HDL}$-cholesterol in relation to socioeconomic status in a sample of 11,645 Greek adults: the EPIC study in Greece. European Prospective Investigation into Nutrition and Cancer. Scand J Public Health 2000;28:260-5.

44. Smith GD, Hart C, Watt G, et al. Individual social class, area-based deprivation, cardiovascular disease risk factors, and mortality: the Renfrew and Paisley Study. J Epidemiol Community Health 1998:52:399-405.

45. Manhem K, Dotevall A, Wilhelmsen L, et al. Social gradients in cardiovascular risk factors and symptoms of Swedish men and women: the Göteborg MONICA Study 1995. J Cardiovasc Risk 2000;7:359-68.

46. Singh RB, Sharma JP, Rastogi V, et al. Social class and coronary disease in rural population of north India. The Indian Social Class and Heart Survey. Eur Heart $J$ 1997;18:588-95.

47. Perova NV, Davis CE, Tao S, et al. Multi-country comparison of plasma lipid relationship to years of schooling in men and women. Int J Epidemiol 2001;30:371-9.

48. Nemesure B, Wu S-Y, Hennis A, et al. Prevalence of obesity and associated sex-specific factors in an African-origin population. Ethn Dis 2007:17:508-14. 